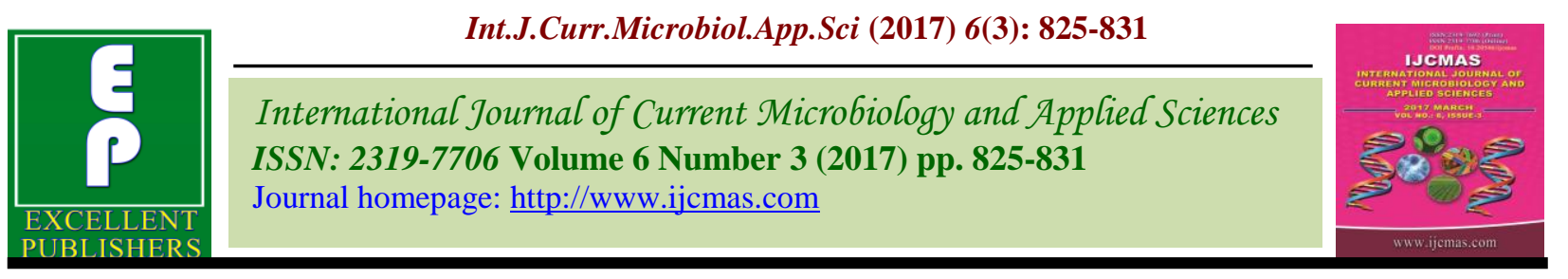

Review Article

https://doi.org/10.20546/ijcmas.2017.603.097

\title{
Turcicum Leaf Blight: A Ubiquitous Foliar Disease of Maize (Zea mays L.)
}

\author{
Dan Singh Jakhar*, Rajesh Singh, Saket Kumar, Pargat Singh and Vivek Ojha \\ Department of Genetics and Plant Breeding, Institute of Agricultural Sciences, \\ Banaras Hindu University, Varanasi - 221005, UP, India \\ *Corresponding author
}

\begin{tabular}{|c|c|}
\hline & A B S T R A C T \\
\hline Keywords & \multirow{4}{*}{$\begin{array}{l}\text { Turcicum leaf blight (TLB) or Northern Corn Leaf Blight (NCLB) is a ubiquitous foliar } \\
\text { disease of corn (maize) caused by Exserohilum turcicum, the anamorph of the ascomycete } \\
\text { Setosphaeria. The TLB fungus survives through the winter on infected maize residue at the } \\
\text { soil surface. As temperatures rise in the spring and early summer, the fungus produces } \\
\text { spores on residue, and then the spores are splashed or wind-blown onto leaves of the new } \\
\text { maize crop. Infection occurs during periods of moderate }\left(64^{\circ} \text { to } 81^{\circ} \mathrm{F}\right) \text {, wet and humid } \\
\text { weather. The disease begins as long, slender, grayish or tan leaf lesions that run parallel to } \\
\text { the mid vein. Lesions can eventually expand to a more oblong or "cigar" shape. Lesions } \\
\text { may also form on husks. Loss of photosynthetic tissue can result in decreased yield, and } \\
\text { silage quality can be affected. Effective management practices that reduce the impact of } \\
\text { TLB include selecting resistant cultivars, reducing maize residue, timely planting and } \\
\text { applying foliar fungicides. }\end{array}$} \\
\hline $\begin{array}{l}\text { Turcicum Leaf } \\
\text { blight, Exserohilum } \\
\text { turcicum, Foliar } \\
\text { Disease, Maize. }\end{array}$ & \\
\hline Article Info & \\
\hline $\begin{array}{l}\text { Accepted: } \\
\text { 15 February } 2017 \\
\text { Available Online: } \\
10 \text { March } 2017\end{array}$ & \\
\hline
\end{tabular}

\section{Introduction}

Maize is the world's third leading cereal crop, after wheat and rice. It most probably originated in Central America, specifically Mexico and spread Northward to Canada and Southward to Argentina. As per the USDA report of May, 2016, the world maize production has been estimated about 96.88 crore tonnes in 2015-16 which is 4.6 per cent lower than last year (101.35 crore tonnes). Turcicum leaf blight is a common disease of maize in many parts of the world including India (Figure 1). Turcicum leaf blight is a common disease of maize in many parts of the world including India. Turcicum Leaf bright incited by the ascomycete Setosphaeria turcica, Anamorph Exserohilum turcicum. It was first reported in the USA in New Jersey in 1878, this was followed by a serious outbreak of Turcicum leaf blight in Connecticut in 1889 (Drechsler, 1923). Turcicum leaf blight is favored by mild temperature and high humidity (Ullstrup, 1970). Heavy dews, cool temperature and frequent rains create good environmental conditions for disease development (Jordan $e t$ al., 1983). TLB in India, the disease is prevalent in Karnataka, Himachal Pradesh, Uttarakhand, Uttar Pradesh, Orissa, Andhra Pradesh, North Eastern Hill state and also affects Rabi maize in plains. It reduces the grain yield of maize considerably all over the world. Grain yield can be reduced to $50 \%$ when TLB become severe before either qualitative (Monogenic) or quantitative (Polygenic) flowering (Raymundo et al., 1981; Tefferi et al., 1996). Resistant cultivars 
have been used extensively to control TLB. Diverse sources of qualitative and quantitative resistance are available. Qualitative or monogenic resistance is race specific often unstable and depends upon environmental conditions. This type of resistance is conferred by Ht genes (Gevers, 1975; Hooker, 1977; 1981; Robbins and Warren, 1993) and by many unnamed genes (Carson, 1995). These genes are mostly characterized by chlorotic lesion responses. Quantitative or polygenic resistance is normally race nonspecific. This type of resistance is expressed independently of physical environment and largely insensitive to varying light and temperature conditions (Carson and van Dyke, 1994). Quantitative TLB resistance is durable in nature and characterized by fewer and sometime smaller lesions and a prolonged incubation period but not reduced sporulation (Ullstrup, 1970; Brewster et al., 1992; Smith and Kinsey, 1993).

\section{Symptoms}

The characteristic symptom of turcicum leaf blight on a susceptible cultivar is one-to-six inch long cigar-shaped gray- to tan-colored lesions on the leaves (Figure 2). However, before lesions are fully developed, they first appear as small light-green to grayish spots approximately 1-2 weeks after infection. As the disease develops, the lesions spread to all leafy structures, including the husks, and produce dark gray spores, giving lesions as dirty appearance. The lesions may become so numerous that the leaves are eventually destroyed, causing major yield loss due to reduction in the available of carbohydrates to fill the grain. The leaves then become grayish-green and brittle, resembling leaves killed by frost.

\section{Races of turcicum leaf blight}

Several physiological races of the fungus are known to occur, including races $0,1,2,12$,
23, 23N and 123N (Table 1). Ferguson and Carson (2007) reported a survey of TLB races which indicated that frequency of Race 0 isolates decreased from $83 \%$ in 1974 to $50 \%$ in the 1990s. Two types of resistance are available to protect against these races: partial resistance (non-race specific), which is controlled by multiple genes and protects against all known races of the fungus, and race-specific resistant, which is controlled by single $\mathrm{Ht}$ genes ( $\mathrm{Ht} 1, \mathrm{Ht} 2, \mathrm{Ht} 3$, and $\mathrm{HtN})$ and, as the name suggests, protects against specific races of the pathogen. Partial resistance and resistance conferred by $H t N$ are expressed as a reduction in the number and size of the lesions, whereas resistance conferred by $\mathrm{Htl}$, $H t 2$, and $H t 3$ is expressed as small chlorotic lesions. A compatible interaction between $\mathrm{Ht}$ genes and races of the pathogen results in a susceptible lesion type, large necrotic cigarshaped lesions (Figure 2) whereas incompatible interactions result in small chlorotic lesions (resistant lesion type). For instance, race 1 of the fungus causes large necrotic cigar-shaped lesions on cultivars with $H t 1$, but small chlorotic lesions on cultivars with $H t 2, H t 3$, or $H t N$.

\section{Disease cycle and epidemiology}

The fungus causing TLB overwinters as mycelia and conidia on maize residues left on the soil surface. Conidia may also be transformed into thick-walled resting spores called chlamydospores. During warm, moist weather in early summer, new conidia are produced on the old maize residue and carried by the wind or rain to lower leaves of young maize plants. Infection and disease development are favored by heavy dew, frequent rainfall, high humidity, and moderate temperatures. Infection by germinating conidia occurs when free water is present on the leaf surface for 6-18 hours and the temperature is between 66 and $80^{\circ} \mathrm{F}(18$ $27^{\circ} \mathrm{C}$ ). Under favorable conditions, lesions develop and produced a new crop of spores 
within 7-12 days on susceptible cultivars, causing the disease to spread rapidly. Secondary spread from lower to upper leaves and among plants within a field results primarily from spores being splashed around by rain, whereas wind is responsible for longdistant spore movement and spread of the disease from one field to another (Figure 3).

\section{Disease inoculation and assessment}

TLB will be induced by inoculation the spreader rows and all plots. Conidial suspensions prepared from $S$. turcica will be used to inoculate each plant at the 4-6 leaf stage. Disease assessment at each location will conducted in the field after onset of the disease. Ten randomly selected plants in the center row will be tag and used for successive disease assessments. Plants will be rated at- 10 day intervals for percent incidence, the number of lesion on the ear leaf and second leaf above the ear leaf on each tagged will also counted two leaves per plants. Disease severity will be rated followed by CIMMYT methods using 1-5 scoring scale (Table 2 \& Figure 4). E. turcicum severity rating will do as follow.

\section{Damage}

Yield loss is caused predominantly through loss of photosynthetic leaf area due to blighting. Under severe infestation, sugars can be diverted from the stalks for grain filling leading to crop lodging. If TLB establishes before silking and spreads to upper leaves during grain filling, severe yield losses can occur. Crop lodging is a particular concern where maize is mechanically harvested. In dry conditions, TLB is rarely an important disease of maize. Yield losses as high as $70 \%$ have been recorded due to TLB. Typically, however, yield losses range from 15 to $30 \%$.

\section{Management practices}

\section{Resistant cultivars}

Planting resistant cultivars is the most effective method for controlling TLB. Partial resistance protects against all four of the known races of the fungus and reduces the rate of disease development by reducing the number and size of the lesions and the amount of spores produced in these lesions, as well as increasing the length of the incubation and latent periods. Race-specific resistance protects against specific races of the fungus, reducing disease development by producing chlorotic lesion with limited and delayed sporulation. Resistant cultivars should be planted in all commercial dent maize production fields. Select cultivars with high levels of partial resistance in combination with $H t 1, H t 2$ or other $H t$ genes.

Table.1 Common sources of resistance $\mathrm{Ht}$ genes

\begin{tabular}{ccccc}
\hline $\begin{array}{c}\text { Races of } \\
\text { Exserohilum } \\
\text { turcicum }\end{array}$ & $\boldsymbol{H t 1}$ & $\boldsymbol{H t 2}$ & $\boldsymbol{H} \boldsymbol{t 3}$ & $\boldsymbol{H} \boldsymbol{t}$ \\
$\mathbf{0}$ & $\mathrm{R}$ & $\mathrm{R}$ & $\mathrm{R}$ & $\mathrm{R}$ \\
$\mathbf{1}$ & $\mathrm{S}$ & $\mathrm{R}$ & $\mathrm{R}$ & $\mathrm{R}$ \\
$\mathbf{2}$ & $\mathrm{R}$ & $\mathrm{S}$ & $\mathrm{R}$ & $\mathrm{R}$ \\
$\mathbf{1 2}$ & $\mathrm{S}$ & $\mathrm{S}$ & $\mathrm{R}$ & $\mathrm{R}$ \\
$\mathbf{2 3}$ & $\mathrm{R}$ & $\mathrm{S}$ & $\mathrm{S}$ & $\mathrm{R}$ \\
$\mathbf{2 3 N}$ & $\mathrm{R}$ & $\mathrm{S}$ & $\mathrm{S}$ & $\mathrm{S}$ \\
$\mathbf{1 2 3 N}$ & $\mathrm{S}$ & $\mathrm{S}$ & $\mathrm{S}$ & $\mathrm{S}$ \\
\hline
\end{tabular}


Table.2 Scoring of Turcicum leaf blight disease

\begin{tabular}{|c|c|c|c|}
\hline Symptoms & $\begin{array}{c}\text { Symptoms } \\
\text { Severity Grade }\end{array}$ & Responsive Value & $\begin{array}{c}\text { Disease } \\
\text { Reaction }\end{array}$ \\
\hline No symptoms & 0 & 0 & Symptom less \\
\hline $\begin{array}{l}\text { Very slight to } \\
\text { Slight infection }\end{array}$ & 1 & $\begin{array}{l}\text { One, two or few scattered lesions } \\
\text { on lower leaves. }\end{array}$ & $\begin{array}{l}\text { Highly } \\
\text { resistant }\end{array}$ \\
\hline Light infection & 2 & $\begin{array}{l}\text { Light infection, Moderate number } \\
\text { of lesion on lower Leaves only }\end{array}$ & Resistant \\
\hline Moderate infection & 3 & $\begin{array}{l}\text { Abundant lesion on lower leaves, } \\
\text { few on middle leaves }\end{array}$ & $\begin{array}{l}\text { Moderately } \\
\text { resistant }\end{array}$ \\
\hline Heavy infection & 4 & $\begin{array}{l}\text { Lesions abundant on lower and } \\
\text { middle leaves, extending to upper } \\
\text { leaves }\end{array}$ & Susceptible \\
\hline $\begin{array}{l}\text { Very heavy } \\
\text { infections }\end{array}$ & 5 & $\begin{array}{l}\text { Lesion abundant on almost all } \\
\text { leaves plants prematurely dry or } \\
\text { killed by the disease. }\end{array}$ & $\begin{array}{l}\text { Highly } \\
\text { susceptible }\end{array}$ \\
\hline
\end{tabular}

Table.3 Maize foliar fungicides and efficacy against NCLB. Adapted from Wise, 2015

\begin{tabular}{|c|c|c|c|}
\hline Fungicide/ & Active Ingradients & Chemical & $\begin{array}{c}\text { NCLB } \\
\end{array}$ \\
\hline $\begin{array}{l}\text { Company } \\
\text { Aproach }\end{array}$ & Picoxystrobin & methoxy- & very good \\
\hline DuPont & & acrylates & \\
\hline $\begin{array}{l}\text { Aproach Prima } \\
\text { DuPont }\end{array}$ & picoxystrobin+cyproconazole & $\begin{array}{c}\text { methoxy- } \\
\text { acrylates \& } \\
\text { triazoles }\end{array}$ & very gooc \\
\hline $\begin{array}{l}\text { Domark }^{\circledR} \\
\text { Valent }\end{array}$ & Tetraconazole & Triazoles & no data \\
\hline $\begin{array}{l}\text { Headline }^{\circledR} \text { AMP } \\
\text { BASF }\end{array}$ & pyraclostrobin + metconazole & $\begin{array}{l}\text { methoxy- } \\
\text { carbamates \& } \\
\text { triazoles }\end{array}$ & very gooc \\
\hline $\begin{array}{l}\text { Headline }{ }^{\circledR} \text { EC } \\
\text { Headline }{ }^{\circledR} \text { SC } \\
\text { BASF }\end{array}$ & Pyraclostrobin & $\begin{array}{c}\text { methoxy- } \\
\text { carbamates }\end{array}$ & very gooc \\
\hline $\begin{array}{l}\text { Quadris }^{\circledR} \\
\text { Syngenta }\end{array}$ & Azoxystrobin & $\begin{array}{l}\text { methoxy- } \\
\text { acrylates }\end{array}$ & Good \\
\hline $\begin{array}{l}\text { Quilt }^{\circledR} \\
\text { Quilt }^{\circledR} \text { Xcel } \\
\text { Syngenta }\end{array}$ & propiconazole \& azoxystrobin & $\begin{array}{l}\text { trizoles \& } \\
\text { methoxy- } \\
\text { acrylates }\end{array}$ & very gooc \\
\hline $\begin{array}{l}\text { Stratego }{ }^{\circledast} \text { YLD } \\
\text { Bayer }\end{array}$ & $\begin{array}{l}\text { prothioconazole \& } \\
\text { trifloxystrobin }\end{array}$ & $\begin{array}{c}\text { trizoles \& } \\
\text { oximino- } \\
\text { acetates }\end{array}$ & very gooc \\
\hline $\begin{array}{l}\text { Tilt } \\
\text { Syngenta }\end{array}$ & Propiconazole & Triazoles & Good \\
\hline
\end{tabular}


Fig.1 Geographic distribution of turcicum leaf blight

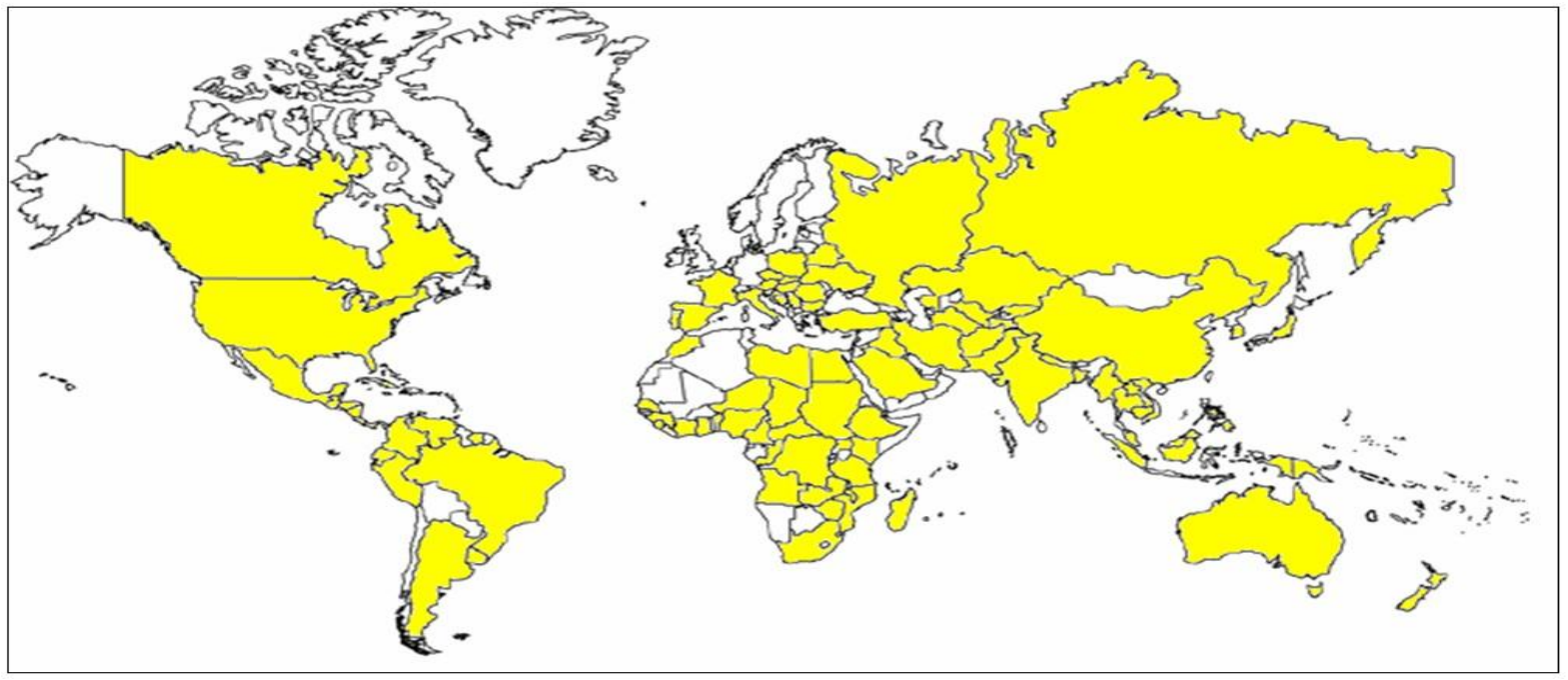

Fig.2 Typical cigar shaped lesion of turcum leaf blight on maize leaf

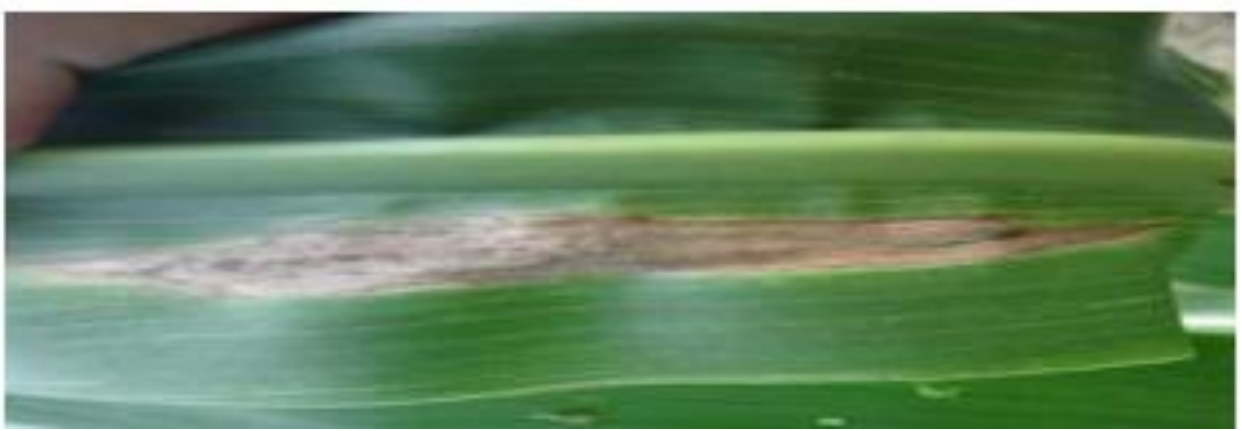

Fig.3 Disease cycle of turcicum leaf blight of maize

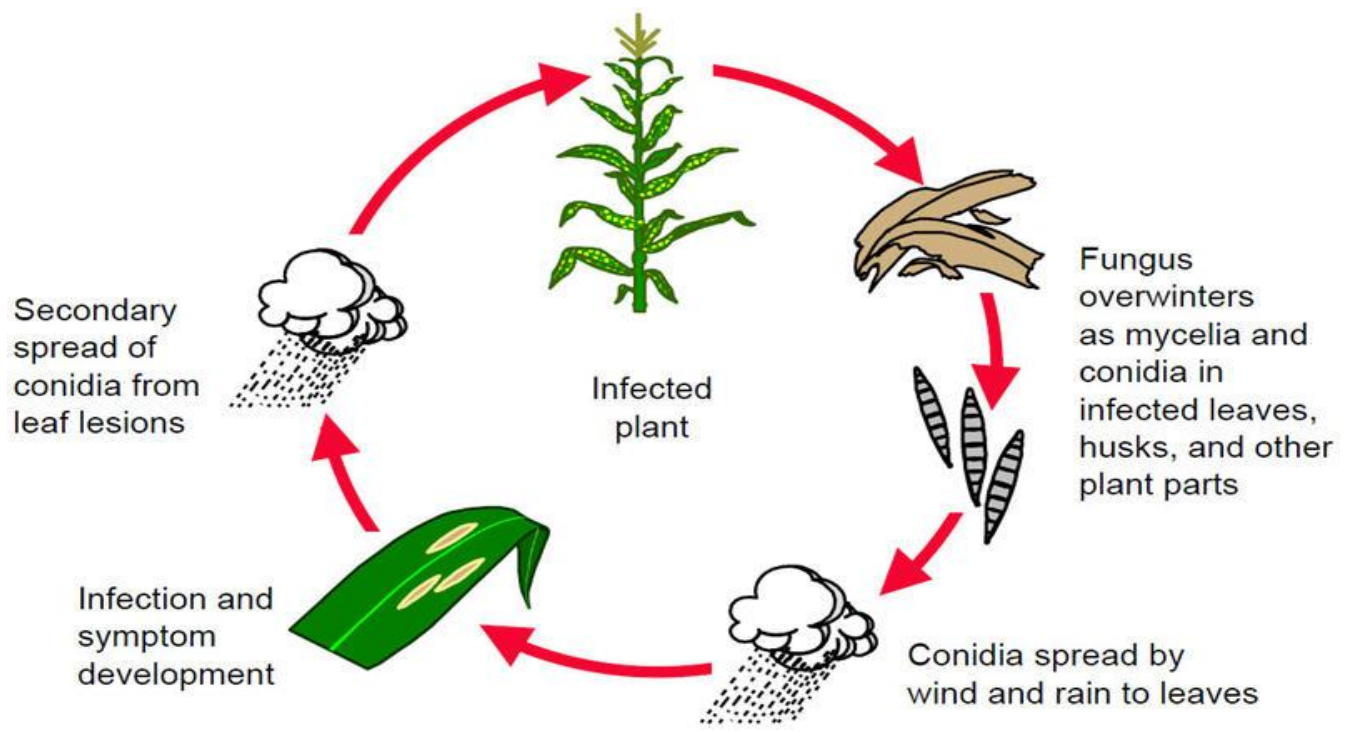


Fig.4 Disease Score (1-5-point scale) for field evaluation of TLB of maize

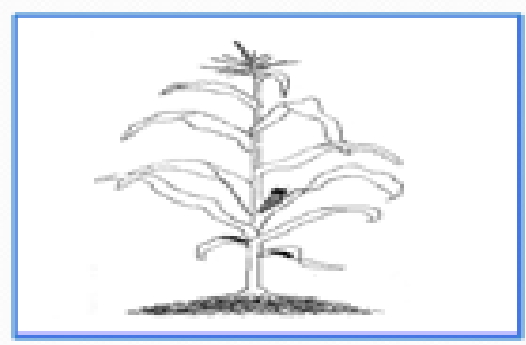

Highly Resistant $(1-1096)$

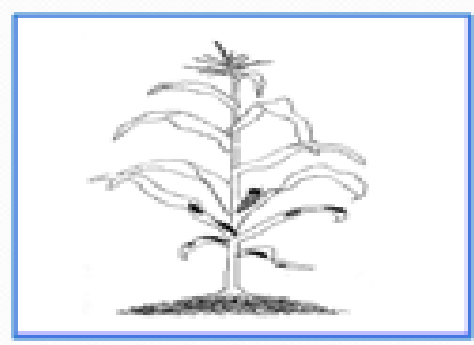

Resistant (2-11-2596)

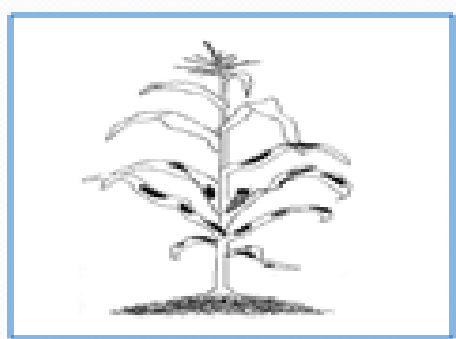

Moderately Resistant $(3-26-50 \%)$

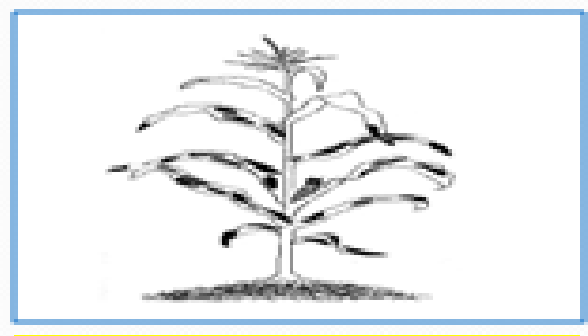

Susceptible (4-51-75\%)

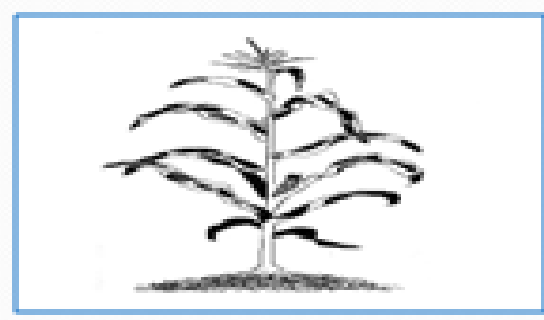

Highly Susceptible 5- (75-100\%)

\section{Reducing previous maize residue}

Reducing maize residue decreases the amount of TLB inoculums available to infect the subsequent crop. A one- to two-year rotation away from maize and destruction of old maize residues by tillage will be helpful for controlling TLB.

\section{Timely planting}

Timely planting can often help cultivars escape the most severe damage from TLB if crop development outpaces normal disease progression. The latest-planted maize in an area may be infected when plants are smaller, resulting in the disease progressing more rapidly relative to the crop. However, in cases of high disease incidence, both early- and late-planted maize may be severely damaged.

\section{Fungicide application}

Various foliar fungicides are available to help control or suppress TLB development (Table 3). Though fungicides are routinely used by growers to protect against several common leaf diseases, TLB may not always be controlled as completely as some other diseases. This is because of the more rapid life cycle of TLB, which may be as short as 1 week under favorable conditions. Because TLB sporulates so rapidly, it is more difficult to time a single fungicide application. Consequently, selecting resistant cultivars is a crucial first step in managing TLB where incidence is historically high.

\section{References}

Brewster, V.A., Carson, M.L., Wicks, Z.W. III. 1992. Mapping components of partial resistance to northern leaf blight of maize using reciprocal translocations. Phytopathol., 82: 225-229.

Carson, M.L. 1995. Inheritance of latent period length in maize infected with Exserohilum turcicum, Plant Dis., 79: 581-585.

Carson, M.L., Van Dyke, C.G. 1994. Effect of light and temperature on expression of partial resistance of maize to 
Exserohilum turcicum. Plant Dis., 78: 519-522.

Drechsler, C. 1923. Some graminicolous species of Helminthosporium. I. J. Agri. Res., 24: 641-739.

Ferguson, L., Carson, M. 2007. Temporal variation in Setosphaeria turcica between 1974 and 1994 and origin of races 1,23 , and $23 \mathrm{~N}$ in the United States. Phytopathol., 97: 1501-1511.

Gevers, H.O. 1975. A new major gene of resistance to Helminthosporium turcicum leaf blight of maize, Plant Dis. Rep., 59: 296-299.

Hooker, A.L. 1977. A second major gene locus in corn for chlorotic lesion resistance to Helminthosporium turcicum. Crop Sci., 17: 132-135.

Hooker, A.L. 1981. Resistance to Helminthosporium turcicum from Tripsacum floridanum incorporated into corn, Maize Genetics Cooperation Newslett., 55: 87-88.

Jordan, E.G, Perkins, J.M., Schall, R.A., Pedersen, W.L. 1983. Occurrence of race 2 of Exserohilum turcicum on corn in the Central United States, Plant Dis.,
67: 1163-1165.

Raymundo, A.D., Parkins, J.M., Hooker, A.L. 1981. Effect of gene $H t N$ on the development of Northern Corn Leaf Blight epidermis. Plant Dis., 65: 327330.

Robbins, W.A., Warren, H.L. 1993. Inheritance resistance to Exserohilum turcicum in PI 209135, "Mayorbela" variety of maize. Maydica, 38: 209-213.

Smith, D.R., Kinsey, J.G. 1993. Latent perioda possible selection tool for Exserohilum turcicum resistance in corn (Zea mays L), Maydica, 38: 205-208.

Tefferi, A., Hulluka, M., Welz, H.G. 1996. Assessment of damage and grain yield loss in maize caused by northern leaf blight in western Ethiopia. J. Plant Dis. Prot., 103: 353-363.

Ullustrup, A.J. 1970. A comparison of monogenic and polygenic resistance to H. turcicum in corn. Phytopathol., 60: 1597-1599.

Wise, K. 2015. Fungicide efficacy for control of corn diseases. Purdue Extension Publication BP-160-W. Purdue University, West Lafayette, Indiana.

\section{How to cite this article:}

Dan Singh Jakhar, Rajesh Singh, Saket Kumar and Pargat Singh. 2017. Turcicum Leaf Blight: A Ubiquitous Foliar Disease of Maize (Zea mays L.). Int.J.Curr.Microbiol.App.Sci. 6(3): 825831. doi: https://doi.org/10.20546/ijcmas.2017.603.097 